This is the version of the article accepted for publication in Journal of Southern African Studies published by Taylor \& Francis: http://www.tandfonline.com/loi/cjss20

Accepted version downloaded from SOAS Research Online: http://eprints.soas.ac.uk/23848/

\title{
'Cape Town knows, but she forgets': segregation and the making of a housing crisis during the first half of the twentieth century
}

\author{
Wayne Dooling \\ School of Oriental and African Studies, University of London
}

\begin{abstract}
The city of Cape Town experienced a severe housing crisis during the first half of the twentieth century, the immediate origins of which were to be found in demographic growth fuelled by natural increase as well as inward migration. The deeper roots of the crisis, however, were in the policy of segregation. This paper examines the consequences of the housing shortage for the city's black population and is concerned with segregation as lived experience. The crisis, the scale of which was much greater than previously appeciated, was at its worst during the interwar years. As local state action failed to keep pace with segregatory legislation, the overwhelming majority of the city's population lived under circumstances that could only be described as appalling. For the majority of Cape Town's black population, the segregationist state of the interwar years was simply absent from the housing market.
\end{abstract}

\section{Introduction}

Punctuated by the First Word War and the Great Depression, the early decades of Union of South Africa were years of rapid and often tumultuous social change. Guiding this new, unified state, was the ideology of racial segregation, explicitly racist in its tone and content. Its paternalist overtones notwithstanding, segregation as policy was distinguished from nineteenth-century precedents by the manner in which previously disparate ideas of white supremacy had coalesced into a coherent doctrine of enforced territorial separation along racial lines. Though the ideology of segregation did not emerge as a coherent whole all at once, it is clear that by the end of the 1920s several pieces of legislation were unified by the desire to entrench a cheap migrant labour system. Perceived as central to the long-term survival of South Africa's mining industry, the migrant labour system was predicated on the idea that rural areas would meet African susbistence needs; that these areas would be 'retribalized' and chiefly authority bolstered; and that African urbanisation would of necessity have to be curtailed. Though the profitability of the mining industry was of overriding importance, these measures were in no small way concerned to contain 
an increasingly strident African nationalism, awake to Garveyite ideas and communist influences.

At the national level, the new state that was founded in 1910 as the final political settlement of the South African War rapidly set to work to put ideology into practice. A mere three years after coming to power, it most famously passed the Natives Land Act, that great Act of rural dispossession and land alienation. Although it would take some decades before the effects of the Act (amended several times over the course of the years) were fully realised, the results were immediate as thousands upon thousands of African families were evicted from conquered lands throughout the South African interior. ${ }^{1}$ The consequences that were felt throughout southern Africa were far reaching: peasant families on white-owned land found the terms of tenancy turned against them, thus unleashing increased levels of generational and gender conflict; migrant labourers were forced to endure longer spells of underground mine labour; and, perhaps most notably, the land set aside for African occupation - the so-called reserves - suffered rapid environmental degradation, deepening levels of acute poverty, and all round immiseration. Thanks to a great deal of historical research carried out over the past few decades, as much concerned with questions of 'structure' as with 'agency' and the lived experiences of black South Africans, we know a great deal about the form that segregation took in the South African countryside during the first half of the twentieth century. ${ }^{2}$

One of the most important consequences of increased poverty in the reserves was the rapid urbanisation of South Africa's black population, a phenomenon that bedevilled the state that was tasked with meeting the competing demands of mining capital, the manufacturing sector, and white agriculture, while at the same time ensuring racial privilege for the white population at the widest level. For the better part of the twentieth century, thus, black urbanisation was at the heart of what white politicians referred to as the 'native question'. Much of this urbanisation, moreover, was of a permanent nature. During the second half of the twentieth

1 The scale and horror of land evictions following immediately upon the passage of the 1913 Act were immortalised in the eyewitness account of S.T. Plaatje, Native life in South Africa (London, 1916).

2 Notable studies include C. Bundy, The rise and fall of the South African peasantry (2nd edition, Cape Town, 1988); T. Keegan, Rural transformations in industrializing South Africa: the southern Highveld to 1914 (Braamfontein, 1986); W. Beinart and C. Bundy, Hidden struggles in rural South Africa: politics and popular movements in the Transkei and Eastern Cape, 1890-1930 (London, 1987); H. Bradford, A taste of freedom: the ICU in rural South Africa, 1924-1930 (New Haven, 1987); C. van Onselen, The seed is mine: the life of Kas Maine, a South African sharecropper, 18941985 (Cape Town, 1996). For the most recent statements on the Natives Land Act, see part special issue of Journal of Southern African Studies: Reflections on the 1913 Land Act and its Legacies, 1913-2013, 40, 4, 2014. 
century nationalist ideologues offered apartheid as the ultimate 'solution' to South Africa's particular racial and economic configuration. But for the first half of the century, the reality of black urbanisation was met with the ideology and apparatus of segregation. With regard to urban centres, the most significant legislative intervention was the Native (Urban Areas) Act passed by the Smuts government in 1923. The Act's primary aim was to prevent Africans from becoming permanent inhabitants of urban areas. Thus it sought to stem the urbanisation of Africans, and of African women in particular, and to curtail African land ownership in cities.

This article examines one aspect of segregation, namely, an acute housing crisis experienced by the black population of the city of Cape Town. Although this paper covers the period from the beginning of the twentieth century through to the eve of apartheid, it is primarily concerned with the crisis of the interwar years, a period during which the city experienced increased levels of inward migration combined with deepening poverty for the black population, as was evidenced in numerous government investigations at the time. Two major commissions in particular - the Native Economic Commission (1932) and the Wilcocks Commission into coloured poverty (1937) - investigated questions of black standards of living and poverty. ${ }^{3}$ The housing crisis had multiple causes, but for the most part it was brought on by the absence of planning at the central level and utmost neglect on the part of the local municipality. The contrast with the apartheid period was stark: during the first half of the twentieth century state planning failed to match ambitious segregatory legislation. Although officials looked to Britain for comparison as they examined conditions under which the urban poor lived, for there the prevalence of slums and housing shortages were well documented, Cape Town experienced nothing like the massive expansion in housing provision witnessed by British cities during the interwar years. ${ }^{4}$ Nor, did the segregationist state entertain the ambitious kind of central planning carried out by French colonial officials in cities such as Dakar or

3 Union of South Africa (hereafter, UG) 22 - '32, Report of Native Economic Commission, 1930-32; UG 54-'37, Report of Commission of Inquiry regarding Cape Coloured Population of the Union of South Africa (Wilcocks Commission).

${ }^{4}$ See J. Stevenson and C. Cook, The slump: Britain and the Great Depression (3rd edition, Harlow, 2010), esp. pp. 28-29. Some 4 million houses were built in Britain during the interwar years (of which 1.5 million were rented out by local authorities), although it has to be remembered that the benefits of this great expansion were unequally distributed among classes; see K. Laybourn, Britain on the breadline (Gloucester, 1990), pp. 78-79. 
Algiers, where the drive for segregation was accompanied by elaborate schemes to redesign urban areas in line with the ideology of 'assimilation'.5

Although we know much about the ideological origins of segregation, we know less about its consequences as lived experience for the very poor in South Africa's major cities. ${ }^{6}$ Unsurprisingly, Johannesburg has enjoyed the lion's share of South Africa's urban history. ${ }^{7}$ Cape Town has been less well served, although there are notable exceptions. ${ }^{8}$ Drawing on a close reading of contemporary newspapers and archival sources, this article shows that the housing crisis was of a scale and depth not

${ }^{5}$ L. Bigon, 'Bubonic plague, colonial ideologies, and urban planning policies: Dakar, Lagos, and Kumasi', Planning Perspectives, 31, 2, 2016, 205-26; G. Wright, The politics of design in French colonial urbanism (Chicago, 1991).

${ }^{6}$ On the origins of segregation, see S. Dubow, Racial segregation and the origins of apartheid in South Africa (London, 1989) and 'Race, civilisation and culture: the elaboration of segregationanist discourse in the inter-war years', in S. Marks and S. Trapido (eds.), The politics of race, class and nationalism in twentieth-century South Africa (London, 1987); M. Legassick, 'British hegemony and the origins of segregation in South Africa, 1901-14', in W. Beinart and S. Dubows (eds.), Segregation and apartheid in twentieth-century South Africa (London and New York, 2003); M. Lacey, Working for boroko (Johannesburg, 1981). For a very useful summary, see N. Worden, The making of modern South Africa (2nd edition, Oxford, 1995).

${ }^{7}$ Of special interest to the concerns addressed in this paper, see P. Bonner et al (eds.), Holding their own ground: class, locality and culture in nineteenth and twentieth-century South Africa (Johannesburg, 1989); P. Bonner et al (eds.), Apartheid's genesis, 1935-1962 (Johannesburg, 1993); P. Bonner, 'Family, crime and political consciousness on the East Rand', Journal of Southern African Studies, 14, 3, 1988, 393-420; P. Bonner and N. Nieftagodien, Alexandra: a history (Johannesburg, 2008); A.G. Cobley discusses the consequences of the implementation of the Native (Urban Areas) Act on the Witwatersrand at some length: Class and consciousness: the black petty bourgeoisie in South Africa, 1924 to 1950 (Westport, 1990), but his primary concern is with the African petty bourgeoisie. Gary Baines has discussed the housing crisis in Port Elizabeth for the first half of the twentieth century: $A$ history of New Brighton, Port Elizabeth, South Africa, 1903-1953: the Detroit of the Union (Lewiston, N.Y., 2002), esp. pp. 63-85.

${ }^{8}$ Especially important are V. Bickford-Smith et al, Cape Town in the twentieth century: an illustrated social history (Cape Town, 1999); V. Bickford-Smith, 'South African urban history, racial segregation and the unique case of Cape Town?', Journal of Southern African Studies, 21, 1, 1995, 63-78. 
previously appreciated. Moreover, the presence in Cape Town of a large and chronically poor coloured population, who were excluded from the terms of the Native (Urban Areas Act), meant that the housing crisis of the interwar years took a somewhat different form. Maynard Swanson has pointed to the centrality of a 'sanitation syndrome' for the imposition of segregation in Cape Town and Port Elizabeth at the beginning of the twentieth century. However, as Christopher Saunders has pointed out, the sanitation syndrome followed upon and was deployed as justification for de facto segregation that preceded the outbreak of the bubonic plague. ${ }^{9}$ By itself, 'sanitation syndrome' operated at the level of ideology and is largely silent on the way in which the urban poor experienced the realities of segregation. In fact, medical professionals of the interwar years were often sympathetic commentators on the appalling conditions under which the poor lived. They doubtless considered residential segregation along racial lines as the natural order of things, but their investigations into the housing conditions of the poor revealed much about those conditions and showed a genuine concern for the deleterious effects of overcrowding. This paper is thus concerned with the lived experiences of segregation for Cape Town's very poor black population during the first half of the twentieth century.

\section{Origins of the housing crisis}

During the interwar years, poverty among Cape Town's black population manifested itself above all in the extreme shortage of housing. The phenomenon was seen for the first time in the immediate aftermath of the final emancipation of slaves in 1838. As rural slaveowners fought hard to immobilise their former slaves, it was especially the city that promised real freedom to the recently liberated during the first heady months of emancipation. Probably encouraged by the presence in Cape Town of a small but visible 'free black' population, an untold proportion of the Cape Colony's 38,000 former slaves made their way to Cape Town, presenting the city with its first experience of mass inward migration. In the absence of formal housing provision of any kind, overcrowding was the inevitable result. It was under these circumstances that Cape Town's first slums were born, delivering substantial boons to property owners. Slumlordism was central to the making of Cape Town's white bourgeosie. ${ }^{10}$

As from 1893, and especially after 1898, as the docks at Table Bay required more and more unskilled labour, Cape Town's freed slaves and their descendants were for

${ }^{9}$ M.W. Swanson, 'The sanitation syndrome: bubonic plague and urban native policy in the Cape Colony, 1900-1909', Journal of African History, 8, 1977, 387-410; C. Saunders, 'The creation of Ndabeni: urban segregation and African resistance in Cape Town', Studies in the history of Cape Town, 1, 1979, 132-66.

10 W. Dooling, Slavery, emancipation and colonial rule in South Africa (Pietermaritzburg, 2007), p. 117. 
the first time joined by significant numbers of Bantu-speaking Africans..$^{11}$ More immigrants, many of whom were refugees, arrived during the South African War of 1899-1902. By 1901 more than 10,000 Africans were to be found living in the city, including about 1,500 dock workers who lived in a specially built compound. The new immigrants lived close to their places of work around the docks, or in neighbourhoods such as District Six, as well as in greater Cape Town.

Whereas a measles epidemic immediately after the ending of slavery resulted in the first official attempt at segregating Cape Town's coloured population, it was the outbreak of the bubonic plague in 1902 that afforded the colonial government the opportunity to segregate the city's African population. Africans who were said to be living in 'unsanitary conditions' in Cape Town's slums were removed to N'dabeni, the 'location' laid out for the purpose and made possible by the Native Reserve Location Act (Cape). The Act defined 'natives' so as to include 'Hottentots', 'Bushmen', and 'Koranna', but specifically excluded those defined as 'Cape Coloured' or 'Malay'. The colonial government implemented the removal at great speed: by March 1901, only little more than a month after the outbreak of the plague, more than 5,000 Africans had been moved to the location; by the middle of that year, some 7,000 Africans lived in N'dabeni. By the time that the South African War had come to an end, therefore, the African population of Cape Town was confined almost entirely to a single location. This was an overwhelmingly male environment: at this time N'dabeni's population included only about 500 women. Even at this early point it was clear that terrible overcrowding existed at N'dabeni: two decades later it was said that the location could 'comfortably' house 3,000 people. ${ }^{12}$

Elsewhere in the city, housing conditions continued to deteriorate and overcrowding became a major problem. By 1904 the average number of people per house had risen to 7.6, up from 6.7 in 1891. Many were not able to find accommodation in these quarters and moved into shacks, thus becoming 'squatters', or took to sleeping in huts or in the open air on the lower slopes of Table Mountain.

11 For the history of Africans in Cape Town in earlier decades, see V. Bickford-Smith, Ethnic pride and racial prejudice in Victorian Cape Town: group idendity and social practice, 1875-1902 (Cambridge, 1995), esp. pp.79-90.

${ }^{12}$ C.C. Saunders, 'The creation of N'dabeni: urban segregation and African resistance in Cape Town', Studies in the History of Cape Town, 1, 1979, p. 172; T.R.H. Davenport, 'The beginnings of urban segregation in South Africa: the Native (Urban Areas) Act of 1923 and its background', Occasional Papers, no. 15, Insitute of Social and Economic Research, Rhodes University, Grahamstown, 1971 , p. 2; UG 22 - '32, Report of the Native Economic Commission; National Archives of South Africa, Cape Town (hereafter, CA), 3/CT 4/1/5/1272, Evidence submitted to the Government Committee on Natives in Urban Areas by W. Brinton and L. Dawson, September 1935; Native Economic Commission, 1930-32, Minutes of Evidence, Evidence of $\mathrm{Mr}$ James Peacock, 29 April 1931; '"No epidemic of crime"', Cape Argus, 14 Nov. 1922. 
Although many Africans left Cape Town during the recession of 1905-06, employment opportunities generated by the Great War (1914-18) led to renewed inward migration. ${ }^{13}$

It was the flu epidemic that revealed the scale of the housing crisis to a white officialdom who were until this time, in the words of Sydney Lavis, 'wilfully blind and deaf' to the situation facing the city's black population. A detailed investigation in the aftermath of the epidemic led the Minister of the Interior to confess that '"the inhabitants of the best portions of most of the towns and villages of the Union became aware for the first time that a large number of their fellow citizens were living like animals."' Overcrowding was the key feature of the 'dreadful revelations of slum life'. In one instance it was reported that 70 people were found living in a four-roomed house; in other instances the poor sought relief from the 'wretched hovel, rooms in which 5, 6, 9 and more persons were herding together as cattle.'14

In part, the crisis was one made of demographic growth. The 1921 census enumerated a countrywide coloured population of 545,548 persons, showing an increase of 3.7 per cent over the first post-Union census of 1911, and an African population of slightly fewer than 4.7 million souls, the latter figure representing an increase of 16.9 percent over the same period. Despite the slow rate of growth of the coloured population in particular - a direct consequence of the great flu epidemic of 1918 which carried off 8,000 - 9,000 Capetonians in its first three weeks - Cape Town at the beginning of the 1920s still had a coloured population in excess of 109,000 people, thus showing an increase of 30,000 in the decade leading up to 1922. By 1936 the city was home to 127,542 coloureds, 13,054 Africans, 151,621 whites and 3,550 'Asiatics'. ${ }^{15}$

It was particularly the rate of urbanisation of the black population that caused the greatest demographic pressure. During the first decade after the founding of the Union, the rapid deterioration of conditions in the reserves was an indisputable consequence of the Natives Land Act of 1913, which fuelled the migration of Africans to the cities. 'The difficulties which the Natives [of the reserves] have to cope with must be experienced to be appreciated,' wrote the Reverend Mtkimkulu of N'dabeni. Most significant was the rate at which African women moved to cities. The First World War was a further spur to urban migration. In 1911 there were 410,161 African men and 97,981 African women in the Union's urban areas. By 1921 the respective figures were 439,707 and 147,293 . While the male urban

${ }^{13}$ Bickford-Smith et al, Cape Town in the twentieth century, p. 37.

14 'In the underworld of Cape Town', Cape Times, 13 Feb. 1922; Report on the Third Census of the Population of the Union, 1921, Part X.

15 Census, 1921, Part I; Housing the coloured worker', Cape Argus, 19 May 1922;

'"No epidemic of crime"', Cape Argus, 14 Nov. 1922; UG 54 - '37, pp.7-13. 
African population thus increased by 7.2 percent during this decade, the number of African women in urban centres had increased by a staggering 50.33 percent. At the same time, the coloured populations of the main cities of the Cape Province all showed substantial increases, while the populations of most of the rural towns in the southwestern districts of the Cape actually decreased. ${ }^{16}$

Cape Town fully participated in these countrywide trends. In 1911 the average monthly population of N'dabeni was estimated at 719. A year later it had risen to 1,022 and steadily increased from this point onwards. The location witnessed significant growth during the First World War, so that the average monthly population in 1918 was counted as 3,561. 'In many large centres', wrote the Cape Argus in 1922, the location, or village, is no longer a place where natives come from the Territories in search of temporary employment. They are permanent abodes. Men and women raise families in them: live and die in them.' That same year the police claimed that 'hundreds, if not thousands of natives' had made their way to Cape Town; at this time the African population of the city was estimated at 8,000 people. By 1926 Cape Town's African population had risen to 11,622, an increase of 36.51 per cent over the 1921 figure. These movements, moreover, were permanent, as suggested by a 21.9 percent increase in the number of African women in Cape Town over the same period. Out of the 4,421 Africans living in N'dabeni in 1929, 1,990 lived in married quarters. White officials recognised that children born in N'dabeni had no knowledge of the countryside; by the mid-1930s it was said that many Africans in Cape Town knew 'nothing of their original homes' and could thus not be 'repatriated'. ${ }^{17}$

To whites in general the urbanisation of Africans during the first half of the 1920s presented itself not as a housing crisis, but alternately as the 'native problem', 'native menace' and, most indelicately, as the 'Kafir invasion'. 'The increasing tendency towards the urbanisation of the natives is another sign of the changing conditions in this country,' editorialised the Cape Argus, 'and seriously adds to the difficulty of the native problem as a whole.' The problem, as some saw it, was that

${ }^{16}$ Statement by Rev. A. Mtkimkulu presented to the Native Economic Commission, vol. 4, 24 April 1931; J.D.R. Rheinhallt Jones, 'The urban native', South African Institute of Race Relations, Wits Historical Papers, AD1715, Item no. 5.7.1.

17 'The location to be moved', Cape Argus, 15 Feb. 1922; 'Natives in urban areas', Cape Argus, 13 June 1922; 'Cape Town flooded with natives', Cape Argus, 31 July 1923; '"No epidemic of crime"', Cape Argus, 14 Nov. 1922; Native Economic Commission, Evidence of Sir Clarkson Henry Tredgold, 23 April 1931; CA 3/CT 4/1/5/1272, S. Cook, Superintendent of Natives - Town Clerk, 14 Aug. 1935; CA 3/CT 4/1/5/1248, 'Ndabeni Location: Report of the Medical Officer of Health Re General Conditions', 21 Dec. 1934; UG. 22 - '32, Report of the Native Economic Commission, 1932; Native Economic Commission, Evidence of Shadick Higgins, 24 April 1931. 
Africans were no longer confined to the location of N'dabeni. According to an estimate of 1922, 7,000 of the 10,000 Africans in the Cape Peninsula lived outside the location and therefore well beyond the purview of officialdom. 'They are under no sort of control, they are not centralised,' complained the police of the Africans who lived outside N'dabeni. ${ }^{18}$

One area where Africans went was the environment of Windermere, situated some six miles from central Cape Town and about one mile square in extent. Windermere developed around the Kensington Reserve, a strip of land contaminated with stercus deposits that was simultaneously home to coloured and white occupants. The area owed its name to the fact that it became heavily flooded during Cape Town's wet winter months, although it bore little resemblance to the bucolic English town after which it was named. Much of the land was initially owned by a single consortium that sold off plots to coloured buyers on hire purchase, the latter in turn letting portions of land to African tenants. Although this arrangement was illegal - the African tenants were deemed squatters - Windermere took in ever increasing numbers of Africans, from around 500 families in 1922 to an estimated 6,436 persons in 1946, at which time it had a total population of 12,130 . Probably the population of the area ebbed and flowed along with the African population of Cape Town as a whole. For much of the first few decades of the twentieth century officials had very little idea of Windermere's population - the area remained beyond municipal control until 1943 - and at least one official readily admitted to ignorance on the subject; others speculated wildly. The reality, however, was that Windermere had become home to significant numbers of Africans, their numbers over time roughly equalling that of the coloured population with whom they lived in close proximity. ${ }^{19}$

Whites saw the solution to the 'native problem' as one that required containment, control, and the implementation of 'law and order.' The city's white middle class responded to the 'abnormal and thoroughly unsatisfactory state of affairs' by criminalising the new immigrants. In February 1922 the Cape Times carried a series of articles on Cape Town's 'underworld' in which N'dabeni stood at the root of criminal evil. Here people had 'abandoned the sanctions of tribal life.' Windermere, the 'haunt of Cape Town's criminals,' ostensibly gave a 'sense of security to the criminal mind.' Among Cape Town's black population there was said to exist the

18 'Town natives', Cape Argus, 14 Jan. 1926; 'Control of natives', Cape Argus, 8 Feb. 1923; '"No epidemic of crime"', Cape Argus, 14 Nov. 1922; 'Cape Town flooded with natives', Cape Argus, 31 July 1923.

${ }^{19}$ CA 3/CT 4/1/9/1/7, Report of P.G. Caudwell, Inspector of Urban Locations, 30 April 1941; 3/CT 4/1/5/1248, G.J. Boyes - Secretary for Native Affairs, 6 Nov. 1922; ibid, H.F. Trey - Secretary of the South African Police, 16 Oct. 1922; 'Peninsula riddled with shebeens', Cape Argus, 22 April 1944; 'The blot of Windermere cannot be obliterated overnight', Cape Times, 20 Feb. 1948. 
'twin scourge of immorality and venereal disease.' 'The safety of our womankind,' was at stake, warned the Cape Argus. ${ }^{20}$

Many whites looked back wistfully to a time before the First World War when the city centre was 'practically free of native residents'. There was 'none of the 'casual floating population that comes from the kraals for six or nine months of each year.' Ordinance 8 of 1905, 'the useful old Cape law', prohibited Africans from living outside of locations (save for registered voters and domestic servants who lived on their employers' premises) and 'gave effective protection to civilisation from the evils which are now assailing it from all quarters.' Then, noted the Deputy Commissioner of Police, 'any Kafir found wandering around the streets at night could be arrested and charged.' The reality, however, was that the colonial government had always struggled to confine Cape Town's African population to the single location (not least because of the shortage of accommodation in N'dabeni), but it was clear that a significant shift took place during the First World War. By the early 1920s the Ordinance was a 'dead letter' as there were streets in central Cape Town that resembled 'Kafir locations of the very worst type.'21

\section{The 'Magna Charta of urbanised natives': the Native (Urban Areas) Act ${ }^{22}$}

These circumstances led Cape Town's ruling class to seek salvation in the the Native (Urban Areas) Act of 1923. The Act, the dream child of Colonel Stallard of the South African Party, laid out the basic principles of urban segregation that were later to be taken up by the apartheid state. As Paul Maylam has noted, it 'represented the first major intervention by the central state in the process of African urbanisation.' At the centre of Stallard's thinking was that South African towns were the creation of whites and that blacks could only be tolerated there for as long as they served the needs of whites. This, he believed, would secure the supply of cheap black labour to the South African economy and prevent the emergence of an African middle class, a category he deemed superfluous. ${ }^{23}$

${ }^{20}$ Saunders, 'From N'dabeni to Langa', p. 195; 'In the underworld', Cape Times, 8 Feb. 1922; 'The native influx', Cape Argus, 1 Aug. 1923; CA 3/CT 4/1/10/1/1/2, Enquiry into certain complaints against Mr. G.P. Cook, 10 May 1927; 'Haunt of Cape Town's criminals', Cape Argus, 8 March 1930; 'Big police raid at Windermere', Cape Times, 15 Sep. 1930.

21 '"No epidemic of crime"', Cape Argus, 14 Nov. 1922; 'In the underworld of Cape Town', Cape Times, 7 Feb. 1922; 'The location to be moved', Cape Argus, 15 Feb. 1922.

22 Evidence of Richard Horbo Godlo, Native Economic Commission, 18 March 1931.

${ }^{23}$ P. Maylam, 'The rise and decline of urban apartheid in South Africa', African Affairs, 89, 354, 1990, pp. 66-67; Davenport, 'The triumph of Colonel Stallard: the 
The Act was undoubtedly a consequence of continued black urbanisation. When Jan Smuts introduced the Bill to parliament, it signalled a recognition on the part of the state that urban Africans had come to stay. The Bill initially promised Africans freehold rights in urban areas, but this proviso, most vociferously resisted by the Orange Free State, was overwhelmingly defeated in the House of Assembly. The Act empowered local authorities to set aside sites for African occupation in locations, 'native villages', or hostels, and to provide dwellings for Africans working in urban areas. African owners of urban property, both within and outside locations, could retain their holdings - a recognition of the fact that enforced sales would leave many aggrieved - but non-exempted Africans (that is, landowners, chiefs, headmen, clergy and men who were not entitled to vote in the Cape) could be compelled to move out of 'white' areas if accommodation in locations was available. An important principle was that the locations were to pay for themselves, thus allowing for the setting up of Native Revenue Accounts to be managed by municipalities. The Act also promised unprecedented control over the movement of African men and women. Africans who came to towns in search of work had to obtain a permit to do so, and those who could not find work in the allotted time had to leave the area, thus handing the power of 'influx control' to local municipalities. All in all, the Native (Urban Areas) Act was to 'establish an entirely new standard of native life in urban areas,' or at least so hoped Cape Town's white bourgeoisie. 'If we want good servants we must give them the stability of home life,' wrote the Cape Argus. ${ }^{24}$

Since municipalities across the Union were reluctant to commit the necessary financial resources, implementation of the Act proceeded in fits and starts. Bloemfontein and Johannesburg adopted it without delay while Port Elizabeth was the last of the large urban centres to be proclaimed in 1937. Although the Act was not implemented in Cape Town until 1926, its passage in 1923 led to immediate developments. In the first instance, the administration of N'dabeni was transferred from the central government to the Cape Town City Council. The move was very much seen as an attempt to exert 'adequate control over the native population' and to give the local municipality the power to implement that section of the Act that allowed for the 'repatriation' of 'idle, dissolute, or disorderly natives.' On the latter score, the Council claimed immediate success: unemployed Africans were returned to the Territories 'to a considerable extent,' and the police set about the task of removing Africans from the city centre to Langa. When the Act was brought to bear

transformation of the Native (Urban Areas) Act between 1923 and 1937', South African Historical Journal, 2, 1, 1970, pp. 77-8; Lacey, Working for boroko, p. 2;

24 T.R.H. Davenport, 'African townsmen?' South African Natives (Urban Areas) legislation through the years', African Affairs, 68, 271, p. 99; 'Natives in urban areas', Cape Argus, 21 June 1922; UG 22 - '32, Report of the Native Economic Commission; 'Native locations bill', Cape Argus, 2 Feb. 1922; 'The Native Urban Areas Bill', Cape Argus, 8 Feb. 1923. 
on Cape Town in April 1926, white officials were clear in their thinking that the new regulations would give them 'systematic control of natives.' Africans in the city were to face 'an entirely new regime,' with the long-term aim to reduce their number in the municipality. ${ }^{25}$

Central to the taking over of N'dabeni by the City Council and the application of the Native (Urban Areas) Act to Cape Town was the idea that an entirely new 'native village' was to be constructed; without it, there could be no hope of 'cleaning up the city.' Planning thus got underway for Langa, the new 'model native township' ultimately intended to house 5,000 men, women and children. Although plans for the new township were initially mooted in the aftermath of the flu epidemic of 1918, they were given renewed impetus with the passage of the Native (Urban Areas) Act. Construction of Langa commenced in 1924. The city's planners had great ambitions for the new development: whereas other townships in South Africa grew up according to the 'requirement of the hour', Langa 'will be created on ... forest and veld at practically one effort.' It was to be the 'embodiment of what is certain to be the best and most up-to-date native township under the Southern Cross' and designed 'on the best examples of modern township planning.' In this context, 'modern' planning meant containment. The first barracks, designed to accommodate 2,000 men, was planned as four blocks in the form of a double rectangle, 'each with only one entrance so that in the event of any disturbance the police can close the gates and isolate the inhabitants.' Langa was not to be N'dabeni where Africans 'practically came and went as they pleased.'

It is clear that control was foremost in the planners' minds:

The administration offices, the residence of the Superintendent of the township, and the police station are centrally and conveniently situated. The man on point duty in the central square will be able to see not only from end to end of the main avenue, but will also be able to look into the big compounds for single men, and right up to the railway station. ${ }^{26}$

25 'Removing natives from the city', Cape Argus, 19 Dec. 1923; 'N'dabeni to change hands?', Cape Argus, 27 Sep. 1924; 'Accommodation for natives', Cape Argus, 26 Nov. 1924; 'Cape Town's record of progress, Cape Argus, 11 Sep. 1925; 'Clearing the city of natives', Cape Argus, 19 April 1926; 'Natives in the Peninsula', Cape Argus, 29 June 1926.

26 Davenport, 'African townsmen?', p. 100; Davenport, 'Triumph of Colonel Stallard', pp. 79-80; CA 3/CT 4/1/5/1272, Statement of evidence to be submitted before the Government Committee on natives in urban areas by W. Brinton, L. Dawson, G. Good, September 1935; CA 3/CT 4/1/10/1/1/2, 'Enquiry into certain complaints against Mr. G.P. Cook, 10 May 1927; 'Removing natives from the city', Cape Argus, 19 Dec. 1923; 'The native township', Cape Argus, 21 Dec. 1923; 'The development of Langa', Written evidence given before the Native Economic Commission, 1931; Evidence of Mr James Peacock, Head Constable, CID, before Native Economic 
When Langa was officially opened in September 1927, it had sufficient barracks accommodation for 2,200 men while the barracks for married couples neared completion. Included in the terms by which the City Council took over control of N'dabeni was the stipulation that the location's population were to be moved to Langa in their entirety, although married couples were allowed to remain in N'dabeni for the time being. But city officials did not count on the extent to which Africans would resist removal, as Christopher Saunders has documented in great detail. Six weeks after Langa had been officially opened, no more than a few hundred Africans had moved there and most of the township's accommodation remained unoccupied. At the beginning of 1930 there were still only 1,340 people living in Langa. The following year a figure of 1,938 was recorded (1,236 men, 339 women and 363 children), but this proved to be a highly shifting population. Four years later the figure was virtually unchanged $(1,986)$. Even those who went to the new township, soon left. 'By 15s and 20s they melt away,' noted the Cape Argus in September 1930, at which time there were only 558 single men in accommodation designed to house 2,910 such persons. Of the 900 men who were forced out of N'dabeni in February 1932, only half arrived in Langa; the remainder simply 'vanished'. The police failed to 'clear' the city centre, and those Africans who disappeared from official surveillance made their homes in places such as Windermere, the latter area continuing to grow in population. In short, and as white observers became painfully aware, Langa's shifting population proved that the township had not induced any "'settlement feeling.'" A visitor thought Langa resembled a 'village of the dead.' 27

There were many reasons for African resistance to the new township: the buildings, Africans complained, 'were like graves', the brick and cement floors and slanted iron roofs that were without ceilings made for very cold homes, and the dwellings lacked light which necessitated the use of candles and lamps. To make matters worse, the cost of living at Langa was very high. Rental rates, on average three times higher than those at N'dabeni, were a special grievance. Probably the greatest resentment was reserved for the decision to prohibit the sale of 'kafir beer' and the proposal to establish a municipal beer hall, about which women in particular complained bitterly. As one woman noted:

Commission, 29 April 1931; extended quotation is from 'The creation of Langa', Cape Argus, 5 Jan. 1924.

27 C.C. Saunders, 'From N'dabeni to Langa', Studies in the History of Cape Town, 1, 1979, pp. 209-10, 216, 219; 'N'dabeni to change hands', Cape Argus, 27 Sep. 1924; 'Like a village of the dead', Cape Argus, 27 Sep. 1930; 'Big police raid at Windermere', Cape Argus, 15 Sep. 1930; Evidence of T. Shadick Higgins before Native Economic Commission, 28 April 1931; 'Comfort and prosperity in the township of Langa', Cape Argus, 26 Oct. 1935. 
We are dead already. The white man's beer is killing us ... Our beer serves as food, and it is as milk to our children. We drink it together as part of our meal. That beer never sends anybody to prison or to jail. Now our sons and our men are always in prison because of the white man's beer. ${ }^{28}$

The failure to populate Langa to the extent that planners had hoped was in some measure a failure of the Native (Urban Areas) Act. One of the consequences of the proclamation of Cape Town was that Africans, including those who would previously have lived on their employers' premises, simply moved into areas where the Act did not apply. The law prohibited landowners from allowing Africans to move onto property within three miles of the boundary of the urban area, but that still left large swathes of land 'unprotected.' 'In all sorts of unexpected places in the thick bush you come across them,' said one senior police officer. ${ }^{29}$

In the medium term, then, it proved difficult to implement the Act, so much so that the Smuts government considered abandoning it during the 1940s. In part, this was due to the fact that the segregationist state lacked the bureaucratic muscle and powers of surveillance to ensure its full implementation (unlike the Apartheid state of later decades). For example, along the suburban railway line, on the land between Retreat and False Bay Stations, large numbers of African families lived in 'shacks and hovels' rented from private landlords. Their numbers were unknown to authorities - at best it could be said to be 'very considerable' - in part because the thick bush and heavy sand dunes enabled residents to escape municipal authorities and the police. 'It is a comparatively easy matter for Natives, who have, for example, been refused permission to enter the urban area, to seek refuge here and to remain undetected, for a time at any rate,' noted Cape Town's Inspector of Urban Locations in 1941. Certainly there was a large enough African population at Retreat for the city council to consider establishing another location there. 30

This is not to say that Africans did not suffer a great deal of police harassment and brutality. The municipality of Cape Town employed two inspectors who were authorised to conduct raids and prosecute 'unexampled natives' under the terms of the Act. On 14 September 1930, for example, some 100 policemen conducted a raid in Windermere to round up Africans who fell foul of the Native (Urban Areas) Act. The raid, 'one of the biggest ever organised in the [Cape] Peninsula,' was planned with great secrecy and carried out in the small hours of the morning. House-to-

28 '"White man's beer is killing us"', Cape Argus, 25 June 1924.

29 'Natives in the Peninsula', Cape Argus, 29 June 1926; 'Bush natives on the Cape Flats', Cape Argus, 2 Aug. 1930.

${ }^{30}$ CA 3/CT 4/1/9/1/7, Report of P.G. Caudwell, 30 April 1941; Davenport, 'African townsmen?', p. 108. 
house searches conducted over a three-hour period resulted in the arrest of 256 Africans. $^{31}$

The raid was followed with a big show trial that attracted, amongst others, members of the African National Congress (ANC), the nationalist organisation founded in 1912. (The South African Communist Party and ANC were at this time well established in N'dabeni where, under the watchful eye of police, they held regular meetings where they condemned government actions.) In all, 240 people were prosecuted for contravening the Act: they were unemployed and resident within three miles of the boundary of the municipal area (by now the Act had been amended so as to give local councils increased powers). The trial itself was a spectacle and appeared to take on carnivalesque proportions:

The environs of the court were thronged all day with hundreds of natives of both sexes. The native interpreter had what was probably the busiest day of his life. The cells below the court were incapable of holding all the arrested men and the overflow poured into the dimly lighted corridors - under strict guard. The scene in and around the court resembled a native location on the [Witwatersrand]. Women nursed babies sitting on the stone parapet around Caledon-square. The babel of native tongues was deafening. Here and there one saw gallons of water being distributed to the friends and relatives of the prisoners. in fact, a little kaffir beer did not come amiss to some of the waiting ones.

In the end, all the accused were fined 10s. or seven days' hard labour. ${ }^{32}$

Despite this visible display of local state power, it was hard to police the city. The police station at Windermere had only four policemen. Authorities recognised that 'complete control' was difficult under the circumstances. Police found it near impossible to navigate the 'disordered mass of tin shanties, hovels, and burrows scattered at random in the dense scrub.' Raids in Windermere were always carried out by fully-armed policemen. During one such operation conducted in March 1930, police found themselves under attack; it was only by using their revolvers and batons that they were able to keep the 'mob of 200 natives and coloured people' at bay. One person was shot through the stomach. During the September raid, the warning of barking dogs and 'cries of "Danger! Danger!" in several languages allowed many to effect their escape. Then, the police estimated, at least 200 people

${ }^{31}$ CA 3/CT 4/1/5/1272, Superintendent of Natives - Town Clerk of Cape Town, 14 Aug. 1935; 'Big police raid at Windermere', CA 4/CT 4/1/71, cutting from Cape Times, 15 Sep. 1930

32 '240 Prisoners charged at Caledon Square', Cape Argus, 15 Sep. 1930; 'Enticing natives into location', Cape Argus, 17 Sep. 1930; CA 3/CT 4/1/2/1246, Report of the Superintendent of Natives, 10 Aug. 1932. 
had managed to slip away into the bush, many having gone to sleep fully clothed, seemingly prepared for an eventuality of this kind. ${ }^{33}$

The Native (Urban Areas) Act thus failed on a number of fronts. Firstly, it failed to stem the movement of Africans to cities. The upward trend that we witnessed for the 1920s continued into the 1930s and beyond, a countrywide phenomenon that became of increasing concern to the central government and resulted in the Native Laws Amendment Act of 1937, legislation designed to remove 'surplus' Africans to rural areas and especially to stem the urbanisation of African women. According to census figures of 1938 there were 15,679 Africans (men, women and children) living within the municipal area of Cape Town, up from 11,622 in 1926. Three years earlier officials thought that Cape Town needed only 7,500 Africans to meet its 'reasonable' labour requirements. Moreover, authorities appeared helpless in controlling the migration of women, many of whom took on work as domestic servants, the preserve of coloured women in Cape Town since the ending of slavery. 'There is now becoming available a new class of female domestic servant - one born and brought up in a town location with more regular and permanent associations,' Rheinhalt Jones wrote of Johannesburg, but the observation probably also applied to Cape Town. The most noticeable increase was of 'unattached women', but it was also believed that women entered the city under the false pretence of being married to the men who accompanied them. Officials found that attempts to 'handle' African women met with little success: their presence in the city was a matter of 'extreme delicacy.' Still, in 1941 African women constituted only 22 per cent of Cape Town's adult African population; boys and girls, however, were exactly equal in number. ${ }^{34}$

The Second World War led to renewed African influx. In 1941 Cape Town was home to 17,000 African adults, out of whom only about 12,000 were counted as being employed. Even though the demands of wartime were seen as being responsible for an 'abnormal influx' of African labour, it was also clear, at least to some, that 'the native now forms part of the economic life of the community and that he has come to stay.' Apart from higher than average wages, Cape Town was thought to hold particular attractions to African labourers. 'The work there is "good" work, - no

33 ibid; 'Among the wilds at Windermere', Cape Argus, 9 Aug. 1930; 'Big police raid at Windermere', Cape Times, 15 Sep. 1930

${ }^{34}$ CA 3/CT 4/1/2/1246, Report of Superintendent of Natives, 10 Aug. 1932; CA 3/CT 4/1/9/1/12, Memorandum from Lionel F. Dawson - Town Clerk, 5 Jan. 1938; Native Economic Commission, Evidence of Dr. Shadick Higgins, 24 Aug. 1931; CA 3/CT 4/1/5/1272, Town Clerk of Cape Town - Superintendent of Natives, 14 Aug. 1935; CA 3/CT 4/1/9/1/7, Report of P.G. Caudwell, 30 April 1941; CA 3/CT 4/1/9/1/33, 'Report of the Native Affairs Committee, 30 May 1944; CA 3/CT 4/1/9/1/9, 'Natives in the Cape Peninsula: Report of Mr. C.W. Clarke, 12 May 1943; Rheinhalt Jones, 'The urban native'. 
This is the version of the article accepted for publication in Journal of Southern African Studies published by Taylor \& Francis: http://www.tandfonline.com/loi/cjss20

Accepted version downloaded from SOAS Research Online: http://eprints.soas.ac.uk/23848/

underground work, no fear of miners' phthisis,' wrote C.B. Hudson, the principal of Clarkesbury Native Training School. ${ }^{35}$

Secondly, the Act failed to confine Africans to the locations. In 1924 thousands of Africans were still living in the city centre. In 1926 only 5,294 (out of 11,622) Africans lived in N'dabeni, the only location at the time. The opening of Langa and destruction of N'dabeni brought no relief to Cape Town's officials. In 1935, out of 9,350 African men, only 1,920 were resident in Cape Town's locations. About 2,000 lived on the premises of their employers, but some 2,500 lived elsewhere. In addition, there were 2,500 registered voters whose occupations were unknown and whose movements the authorities were powerless to control. At the same time, 646 African women were housed in the locations, but authorities had no record whatever of the numbers of women resident elsewhere. In 1941 fewer than half of Cape Town's African population lived in Langa, still the only African location in the city. Of the 12,000 Africans in the city who were counted as being employed, a mere 3,000 were thought to be living in Langa. Cape Town's Inspector of Urban Locations admitted that the city had failed to segregate the African population 'in any great measure.' By then the Council had come to recognise that it was hopeless to seek to confine the city's African population to just one location. ${ }^{36}$

Finally, the Act failed to provide Africans with adequate housing, itself a reason for its failure on other fronts. As we have seen, housing provision for the city's black population had long been inadequate. On the eve of the passage of the Native Urban Areas Act, Cape Town faced an acute housing crisis. Conditions here were said to be worse than anywhere else in the Union. Authorities admitted that those who entered the city during the early 1920s had 'nowhere to go', as a result of which there was a large class of 'practically homeless natives.' In the city's slums ten or fifteen people could be seen 'herded in one room, enduring an atmosphere that would kill a less hardy race,' noted the Cape Times in 1922. The problem manifested itself in racially mixed neighbourhoods such as District Six. As housing provision at N'dabeni proved inadequate - in 1927 conditions there were said to 'both disgraceful and dangerous' - there was 'practically no street in District Six' that did not have African residents. People evicted from N'dabeni simply moved to the city

35 CA 3/CT 4/1/9/1/8, Government Departmental Committee to explore ways and means of improving health and social conditions of natives in urban areas other than increasing wages (Smit Committee), Evidence of Dr. Shadick Higgins, 23 Oct. 1941; CA 3/CT 4/2/1/1/612, City Engineer - Chairman and Members of the Finance and General Purpose Committee, 6 Sep. 1941; CA 3/CT 4/1/9/1/9, 'Natives in the Cape Peninsula: Report of Mr. C.W. Clarke, 12 May 1943; Wits Historical Papers, SAIRR, C.B. Hudson - Secretary, Institute of Race Relations, 5 Sep. 1944

${ }^{36}$ Native Economic Commission, Evidence of Shadick Higgins, 28 April 1931; CA 3/CT 4/1/5/1272, Superintendent of Natives - Town Clerk of Cape Town, 14 Aug. 1935; CA 3/CT 4/1/9/1/7, Report of P.G. Caudwell, 30 April 1941. 
itself or to places such as Windermere and Retreat. In the city, tenants were found crowded into dwellings 'to an appalling degree', where their rental payments often bought them no more than sleeping space on a floor. In 1922, for example, 75 people were found crammed into a single, three-bedroom house in District Six's Rose Street. And where space could not be found in District Six, 'hundreds' continued to make their way to the slopes of Table Mountain. In short, as one Cape Town magistrate noted:

The position of the natives down here is about as unsatisfactory as possible, large numbers are dossing in Cape Town and the rooms that they sleep in are very overcrowded and the large numbers residing in the city under very uncomfortable conditions is ... a menace to the other inhabitants of this City ... The whole question of Native housing is as bad as it possibly can be. ${ }^{37}$

Conditions did not improve in subsequent decades. In 1930 it was estimated that 7,000 new houses would have to be built to reduce the housing shortage to the level at which it stood in 1915, and that a further 1,000 would have to be added each year to cope with the city's increased population. As late as 1941 tenements in District Six were reported to hold 'innumerable groups of Natives or families each paying rent for a single room.' These buildings had no special cooking facilities, for the kitchens too had been let to families as living quarters. Food was prepared in living rooms on oil stoves. In one street, people were found to be living 'literally in layers', with rickety ladders providing access to the upper sections. According to figures produced in 1943, only 8,777 out of 23,000 Africans who served the 'normal' labour needs of Cape Town had been provided with housing (5,592 at Langa by the city council, and the remainder by employers), which left some 14,300 Africans unprovided for. The housing at Langa consisted of 828 houses, 444 rooms for single men, and 119 barracks-style dormitories, but wartime migration left the township fully occupied. 38

37 'Native welfare', Cape Times, 6 Feb. 1922; 'In the underworld', Cape Times, 6 Feb. 1922; ibid, 7 Feb. 1922; ibid, 8 Feb. 1922; '"No epidemic of crime"', Cape Argus, 14 Nov. 1922; CA 3/CT 4/1/10/1/1/1, Minute containing representations submitted on behalf of the Women's Municipal Association at an informal meeting of the native township committee, 19 April 1923; 'Cape Town flooded with natives', Cape Argus, 31 July 1923; Saunders, 'From N'dabeni to Langa', pp. 198-99; CA 3/CT 4/1/10/1/1/2, Secretary for Native Affairs - Town Clerk 10 May 1927, enclosure; CA 3/CT 4/1/5/1248, George J. Boyes - Secretary for Native Affairs, 6 Nov. 1922; extended quotation is from CA 3/CT 4/1/5/1248, G.J. Boys - Secretary for Native Affairs, 6 Nov. 1922.

38 'How Cape Town is growing', Cape Argus, 8 Aug. 1930; CA 3/CT 4/1/9/1/6, S.A. Rogers - Acting Town Clerk, 16 Oct. 1941; CA 3/CT 4/1/9/1/9, Greater Langa, Report of P.G. Caudwell, 21 April 1943; CT 4/2/1/1/6/2, Report of P.G. Caudwell, 30 April 1941; CA 3/CT 4/1/9/1/7, F. Gale - J.H Whitaker, 7 April 1943. 


\section{Onto the Cape Flats}

Cape Town's housing crisis of the first half of the twentieth century was seen and experienced in racial terms. Many drew a direct connection between the entry of Africans into Cape Town and an acute housing shortage among coloured residents, by far the largest proportion (around 91 per cent in 1935) of Cape Town's black population. 'As every coloured man knows, since the natives have come into Cape Town it is much harder for the coloured people to get rooms,' wrote the then Canon Sydney Lavis, a man of otherwise liberal sympathies and the most vociferous white champion of the coloured population during the interwar years. Lavis welcomed the Native (Urban Areas) Act and argued for the removal of Africans from the city. 'These natives,' he told the Economic and Wages Commission, 'were in direct competition with the coloured people in the matter of housing accommodation with the advantage on their side. Landlords whose only view as money welcomed them as tenants because any number would crowd into one room.'

As we have seen, the flu epidemic of 1918 revealed the scale and extent of the housing shortage among city's coloured population in particular. This knowledge, however, led to no lasting improvement. 'Cape Town knows, but she forgets,' said Sydney Lavis in 1922, as the city was again reminded of its 'slum horrors.' By the early 1920s, as demographic recovery got underway, housing conditions for the coloured population were 'worse than at any previous stage in the history of Cape Town.' In neighbourhoods such as District Six multiple families were often found to occupy a single room, 'crowded to suffocation.' Terrible overcrowding was also found elsewhere on the fringes of the city centre:

A walk through the districts where the coloured population are housed reveal a very bad state of affairs. Old Dutch houses tumbling into ruin and lotted with debris are crammed with coloured families who eke out an existence in these crowded streets. Many of these houses have since been converted into stores, with the result that the coloured people who inhabited them have been forced to crowd into other houses, thus making the congestion even worse.

In 1924 one particularly appalling case drew the attention of a Cape Town magistrate. At a house in Albert Road, Woodstock, a few metres away from St. Mary's Church, 30 adults and 25 children were found living in a single room. The house, which also served as a brothel, provided accommodation to many families. The structure, noted the magistrate after a personal inspection, was a 'veritable warren overrun with human beings':

To some of the families privacy had been assured by a rough screen of sacks - for the rest there was nothing but a collection of beds huddled out of range of the draught which sweeps between the two doorways ... The barn ... opened into a room used as a kitchen, and this again gave access to a yard where more families were housed. In about of this warren thronged children of both sexes and all ages. 
By the mid-1920s the housing shortage among Cape Town's coloured population was a 'crying evil', or at least so recognised some among the city's middle class. ${ }^{39}$

Conditions arguably deteriorated during the Depression years of the 1930s. Though Cape Town's coloured population showed a steady increase of around 4,000 per year at this time, hardly any additional houses were built with the poor in mind. Moreover, the city council failed to replace the dwellings torn down in District Six under the banner of 'slum clearance.' A housing survey of central Cape Town in the middle of the decade revealed very high levels of overcrowding: 5,231 houses and flats were occupied by 45,855 persons, 88 percent of whom were coloured. However, these houses were let to several different tenants, while single-room lettings constituted more than half of the 12,108 letting arrangements. In sum, 23,917 persons, more than half of the population of the area surveyed, occupied 7,888 single rooms. In many cases, a household was to be found in every room of houses so let. In just one example, a family of seven comprising two parents, four grown-up children (two sons and two daughters) and a nine-year old girl were all found living in a single room. It was not uncommon to find houses with four of five rooms housing as many families with shared use of the bathrooms, kitchens and backyards. In the most extreme cases, up to three families could be found living in a single room. 'In tiny single rooms these Coloured people live together,' noted one newspaper report, 'sometimes two or three families in one room, sometimes in lofts - in cellars, or underground rooms, whose only light and air comes from the door, or in adapted stables.' Circumstances of this nature could only bring misery:

In a miserable little hokkie [shack] opening in into a tiny back yard in Sir Lowry-road lives an old coloured woman with her four children. A single bed pressed against the wall leaves only standing room, besides the corner occupied by a bundle which opens out at night into a second bed on the floor. All the household goods are contained in paper bags hanging by their strings from hooks on the wall ... When the second bed is spread out nobody can move about in the room, and if the window is open on to the foul yard no one can escape the draught from it. ${ }^{40}$

The fundamental reason for these conditions was that a severe shortage of housing stock put the cost of adequate accommodation beyond the reach of the poor. Among

39 'The native problem', Cape Argus, 2 Feb. 1922; 'Housing the coloured worker', Cape Argus, 19 May 1922; 'For the children's sake', Cape Argus, 1 Feb. 1923; 'In the underworld of Cape Town', Cape Times, 13 Feb. 1922; '55 Living in one room', Cape Argus, 11 Nov. 1924; 'Money wasted on pleasure', Cape Argus, 4 Nov. 1925; 'Marion Institute', Cape Argus, 15 Feb. 1922; 'Marion Institute, Cape Argus, 18 May 1922; Pinnock, 'Argie boys', p. 134; 'Housing the poor', Cape Argus, 5 Aug. 1925.

40 'Where South Africa's coloured midwives are trained', The Sun, 23 April 1937; 'How Cape Town is growing', Cape Argus, 8 Aug. 1930; Wilcocks Commission, Evidence of Dr. T. Shadick Higgins, 1 May 1935 and Evidence of Joseph de Kock, 29 March 1935; 'Where South Africa's coloured midwives are trained', The Sun, 23 April 1937; 'Plight of the city poor', Cape Argus, 14 June 1935. 
the coloured population fortunate enough to be in paid employment, rental accommodation typically consumed more than 25 per cent of weekly earnings: 'taking into account their small incomes it is clear that this is far too large a proportion of their wages,' noted the Wilcocks Commission concerned with coloured poverty. With an expanding population - over the five years leading up to 1935 the coloured population increased at a rate of 25.1 per 1,000 , a figure that was 2.6 times greater than that of the white population - the slumlords who monopolised the property market in neighbourhoods such as District Six could continue to charge extortionate rents. Letting properties by the room, simply bought in greater profits. ${ }^{41}$

Recognising that there was no place for the poor in a laissez-faire - and racist property market, sympathetic commentators urged the intervention of local authorities and of the central government. 'The housing problem is essentially one, whether concerned with white or coloured. The two races obtain their accommodation in the same market,' wrote Cape Town's Chief Medical Officer of Health in 1935, 'and they get what they pay for.' He estimated that at least 12,000 dwellings were required to meet the demands of a rising population. ${ }^{42}$

However, early attempts on the part of the Cape Town City Council to address the problem amounted to nil. In part, this was a consequence of the fact that many councillors were themselves slumlords and had a vested interest in the status quo. But it was in large measure also due to the drive for racial segregation on the part of the city's white middle class. The Native (Urban Areas) Act did not apply to the coloured population and Cape Town's white middle class had to find alternative means to retain pristine white suburbs. When, in 1930, the City Council put forward plans to establish a housing scheme in the predominantly white neighbourhood of Mowbray, the neighbourhood's ratepayers' association collected a petition of 300 signatures in opposition to the proposal. The scheme, which was designed specifically to address overcrowding in District Six, 'will not be an acquisition to one of the nicest parts of the [Cape] Peninsula,' the ratepayers claimed. The plan, they argued, was designed for a 'class that should be kept in some other part altogether ... They will spoil it for the residents already there, and they will spoil it for the future.' As a consequence of objections of this nature, housing schemes for the poor remained 'a matter of paper and not of fact.' When, towards the end of the 1930s, the Cape Town City Council began to make a serious start with tackling the housing crisis, plans went hand in hand with driving through racial segregation and pushing black families further and further out of the city. New settlements, moreover, were not built for the very poor. For example, the 500-cottage housing estate at

41 Wilcocks Commission, Evidence of Joseph de Kock, 29 March 1935; Bishop S.W. Lavis, 'The hell in which the coloured man lives', The Sun, 8 July 1938.

42 Wilcocks Commission, Evidence of Dr. T. Shadick Higgins, 1 May 1935. 
Bokmakirie was intended for 'the respectable class of coloured worker' and 'deserving families' who could provide 'good references.' 43

In the absence of adequate housing, then, Cape Town's poor took to the Cape Flats, the sandy expanse east of the city centre and bounded by the sweeping arc of False Bay in the south. Here they built pondokkies, dwellings most commonly fashioned out of second-hand or rusted galvanised iron drums, petrol tins, and sacking. In 1930 authorities estimated that about 2,000 Africans in Cape Town lived in pondokkies, but coloureds constituted the vast majority of people who lived in such settlements. Equally, pondokkies housed the majority of the coloured population. 'Faced with a famine in houses ... the coloured man has acquired his own tools and material and set about building his own houses,' noted the Cape Argus. The worst examples consisted of no more than 'a few pieces of iron sheeting nailed to wooden posts':

The pondokkie of the Cape Flats, in its design, owes nought to any school of architecture, European or Asiatic, ancient or modern. Its conception is determined entirely by the scraps of material which go into its structure, pieces of corrugated iron, old tins and drums, rough boughs, sacking, anything which can possibly offer protection against the weather. Piece by piece, scrap material is bought, begged or filched and added to make room for a growing family. There are no windows, ceilings, and very often no door. Sanitation is non-existent. Many of these hovels would do a disservice to animals. The pondokkie is the lowest standard of human habitation, and the term is not used to describe houses which, though producing similar insanitary conditions, at least conform to elementary standards of architectural design. ${ }^{44}$

Overcrowding in these settlements was no less common than in central Cape Town. This was partly a consequence of the tenure system whereby speculative land companies sold off plots of land to poor households on hire-purchase agreements. Plots could typically be bought for $£ 40$ to $£ 60$ and repaid in instalments of 10 s. to 12s. per month. However, plots and dwellings were frequently sub-let to households unable to enter contractual agreements of their own. As was the case with slum properties in the city, pondokkies on the Cape Flats typically housed seven or eight people, crowded into single rooms. Taken as a whole, tens of thousands of Cape

43 'Klipfontein Road Scheme Rejected', Cape Argus, 28 May 1930; 'The Cape Town skolly menace', The Sun, 20 Aug. 1937; Wilcocks Commission, Evidence of Dr. T. Shadick Higgins, 1 May 1935; Bickford-Smith et al, Cape Town in the twentieth century, p. 149; 'Escape from the slums', Cape Argus, 19 June 1935.

44 'Housing the coloured worker', Cape Argus, 19 May 1922; 'Bush natives on the Cape Flats', Cape Argus, 2 Aug. 1930; Cape Flats Commission, 1942, Chapter VI, pp.14; 'Plight of the coloured', Cape Argus, 20 May 1937; Wilcocks Commission Report, pp. 106-23; CA 3/CT 4/1/9/1/8, Government Departmental Committee to explore ways and means of improving health and social conditions of natives in urban areas other than increasing wages, 1941 (Smit Committee). 
Town's poor were, in the words of Bishop Sydney Lavis, 'victims of civilisation's crowning dishonour - the "one-room family."'45

In Windermere, where Africans and coloureds lived in close proximity and under similar circumstances, conditions were thought to be among the worst. Here groups of shacks were erected in backyards with each room or shack leased separately. Landlords typically kept no record of the number of persons residing on their properties as they tended to make a single person responsible for paying the rent on rooms and shacks. Inspectors of the Native Economic Commission found that in some properties there were as many occupants per room as could be accommodated on the floor; 'about ten occupy a room and only one pays and brings in the others', noted Head Constable James Peacock of the CID.

Such tenants were probably the fortunate ones. In 1930 'hundreds of tin shanties' were seen going up in the bush at Windermere, the area's population fuelled by the entry of a new wave of migrants ('raw natives' from 'the interior'). Such people lived in dwellings fashioned out of paraffin tins, sacking, planks, or 'any other rubbish they [could] lay their hands on.' During the Second World War ever more Africans made their way to Windermere - 5,000 were said to be employed at the adjacent aerodrome in 1943 - with the result that levels of overcrowding increased further still. By this time, the city council had identified Windermere, a 'festering sore on the side of the main body of Cape Town,' as the one area that required the most urgent attention. ${ }^{46}$

Well into the 1940s and beyond pondokkies continued to mushroom in among the dunes of the Cape Flats, many having been erected by landlords themselves. Conditions in these settlements could only be described as deplorable. These environments were roundly condemned as unsanitary. At Retreat, sanitation was non-existent:

45 Cape Flats Commission, 1942, 'Parkwood survey', p. 15; 'Pondokkies on the Cape Flats', Cape Argus, 24 April 1937; 'The Cape Town skolly menace', The Sun, 20 Aug. 1937.

46 'Haunt of Cape Town's criminals', Cape Argus, 8 March 1930; 'Big police raid at Windermere', Cape Times, 15 Sep. 1930; CA 3/CT 4/2/1/1/6/2, Report of P.G. Caudwell, 30 April 1941; CA 3/CT 4/2/1/1/6/2, City Engineer - Chairman and Members of the Finance and General Purpose Committee, 6 Sep. 1941; UG.22-1932, Report of the Native Economic Commission; Native Economic Commission, Evidence of James Peacock, 29 April 1931; CA 3/CT 4/1/9/1/7, Report of P.G. Caudwell, 30 April 1941; CA 3/CT 4/1/9/1/9, Manager of Native Administration - Chairman and Members of the Board of the Native Affairs Committee, 12 May 1943. 
This is the version of the article accepted for publication in Journal of Southern African Studies published by Taylor \& Francis: http://www.tandfonline.com/loi/cjss20

Accepted version downloaded from SOAS Research Online: http://eprints.soas.ac.uk/23848/

For water the people dig holes and water is consequently subject to gross pollution. Pigstys [sic] are frequent accessories to the most evil-smelling places they are. In one case the deposit of filth in which the pigs were grovelling was at least 18 " thick.

On the Parkwood Estate near Wynberg, described as 'the Middletown of the Cape Flats' in the sense that it was not the very worst of such settlements, there was no reticulated water supply. Water had to be drawn from open wells, for not a single tap had been provided for the settlement. Not one dwelling had washing or bathroom facilities. Here, where 36 per cent of all homes were deemed overcrowded, human waste was deposited in small outhouses containing paraffin tins, or buried in the open. Out of 5,834 dwellings counted in 1937, fully 36.5 per cent, or 1,956 units, were found to be unfit for human habitation. Five years later, the number of units that fell into this category had more than doubled.

Similar conditions prevailed at Windermere. Here, too, the vast majority of dwellings were deemed unfit for habitation. The area was said to constitute a 'grave menace', on account of 'the extremely unsanitary conditions and the large extent of the insanitary area.' The area had no sewerage or rubbish collection service, and waste was either buried on vacant land or inhabited plots, with results 'too awful to contemplate.' During the winter months much of the neighbourhood turned into a 'quagmire.' In 1941 only about half of the dwellings there were connected to a regular water supply; the remainder were served by standpipes, where residents bought water by the can at vastly inflated rates, providing further earnings to landlords. Conditions were serious enough for the City Council to consider removing all of Windermere's population. In 1946, however, Windermere retained a population in excess of 14,000 people, including 7,138 coloureds and 6,436 Africans. The area continued to invite condemnation. 'The blot of Windermere cannot be obliterated overnight,' opined the Cape Times in 1948. Ultimately, the 'solution' was defined in racial terms: all of African Windermere's African population were forcibly moved to Langa while a new housing development (Factreton) was commenced to alleviate the housing crisis among coloured residents of the area, a model that was to be greatly elaborated by apartheid planners in subsequent decades. ${ }^{47}$

\section{Conclusion}

The consequences of segregation for Cape Town's black population - African and coloured - were numerous, but one of the most visible manifestations was an acute housing shortage. Almost all who witnessed the state of affairs first-hand were

47 'Housing Surveys', Cape Flats Commission, 1942, p. 15; CA 3/CT 4/1/9/1/8, Native Affairs Commission, Use and and supply of kaffir beer in urban areas and removal of redundant natives from urban areas, 1941/42; CA 3/CT 4/1/9/17, Dr. T. Shadick Higgins - Chairman and Members, General Purposes Committee, 9 Sep. 1941; CA 3/CT 4/2/1/6/2, Report of P.G. Caudwell, Inspector of Urban Locations, 30 April 1941; Cape Times, 20 Feb. 1948. 
united in the view that conditions during the first half of the twentieth century were horrific. Levels of overcrowding were extreme and there was little doubt that the consequences for the city's black population were ruinous. In short, the majority of Cape Town's population lived in circumstances deemed unfit for human habitation. The consequences were chronic ill health and shortened lifespans.

Housing provision in new locations created for African occupation never kept pace with demographic growth. At N'dabeni, established by the colonial government following the outbreak of bubonic plague at the beginning of the century, conditions rapidly deteriorated. The 'model township' at Langa, hastened along by the Cape Town City Council after the passage of the Native (Urban Areas) Act of 1923, met with much resistance, for here rents were high and controls rigid. Instead, Africans remained in neighbourhoods such as District Six, where overcrowding was rife, or, after the destruction of N'dabeni, moved out to areas such as Wingfield where, in close proximity to the neighbourhood's coloured population, they lived in dire conditions and under constant threat of police raids. The Native (Urban Areas) Act thus failed on a number of fronts.

Cape Town's coloured population, for whom state housing was simply absent, were overwhelmingly at the mercy of rack-renting landlords who had a great financial interest in maintaining the status quo. It paid to let single houses to multiple households. Many simply lived in the open. But mostly the poor who were forced out of overcrowded rooms in the city centre took to the sandy expanse of the Cape Flats where makeshift pondokkies provided the most basic shelter. Overcrowding in these quarters were equally bad, for pondokkie dwellers were as likely to be in the grasp of landlords, although the latter were often coloured. Sanitation provision in such settlements was mostly absent. It was only towards the end of the 1930s that the state began to make a serious attempt to address the crisis, but the philosophy of segregation ensured that housing provision for the very poor would fall well short of demand. White residents, moreover, fought to keep black households out of the suburbs. To the extent that the state did provide housing, it was on a very limited scale for the 'respectable' poor. As far as the majority of the black population were concerned, the segregationist state was absent from Cape Town's housing market. Mass housing was to be apartheid's legacy. 